Turkish Psychological Counseling and Guidance Journal

Türk Psikolojik Danışma ve Rehberlik Dergisi
Fidan \& Bulut Serin (2021)

Vol: 11 Number: 63 Page: 577-590 ISSN: 1302-1370

\title{
An Examination of the Relationship between Anger, Aggression, and Problem Solving Skills in Secondary School Students
}

\author{
Ortaokul Ögrencilerinde Öfke, Saldırganlık ve Problem Çözme Becerileri Arasindaki İlişkinin İncelenmesi
}

\section{Bilge Fidan ${ }^{(0)}$, Nergüz Bulut Serin}

\section{Authors Information \\ Bilge Fidan \\ Psychological Counselor, Ministry of National Education, Manisa, Turkey bilgefidan45@gmail.com \\ Nergüz Bulut Serin}

Professor, Department of Guidance and Psychological Counseling, European University of Lefke, Northern Cyprus, TR-10, Mersin, Turkey nserin@,eul.edu.tr

\begin{abstract}
The purpose of this study was to examine if there is a connection between anger, aggression, and problem-solving abilities in secondary school students. The study's sample includes 273 students enrolled in secondary schools in Manisa for the 20202021 academic year. The convenience sampling method, which is one of the nonrandom sampling methods, was used to determine the study's sample. The data for the study was collected using the Anger Scale for Children, the Aggression Scale, and the Problem-Solving Inventory for Children. The t-test, Spearman Correlation analysis, and multiple regression analysis were conducted to analyse the data. Looking at the data, it was determined that the anger levels of female students were higher than those of male students. The aggression levels of male students are higher than female students. It was discovered that anger and aggression have a positive relationship, whereas anger levels have a negative relationship with self-control, avoidance, and total problem solving. Another outcome of the study is that problem-solving abilities predict anger and aggression. A negative association was shown between problem solving, anger, and agression among students.
\end{abstract}

\begin{tabular}{l}
\hline Article Information \\
\hline Keywords \\
Anger \\
Aggression \\
Problem Solving \\
Secondary School Students \\
Anahtar Kelimeler \\
Öfke \\
Saldırganlı \\
Problem Çözme \\
Ortaokul Öğrencileri \\
Article History \\
Received: $21 / 09 / 2021$ \\
Revision: $07 / 12 / 2021$ \\
Accepted: $10 / 12 / 2021$
\end{tabular}

\begin{abstract}
ÖZET
Bu araştırma, ortaokul öğrencilerinde öfke, saldırganlık ve problem çözme becerileri arasındaki ilişkiyi incelemek amacıyla yapılmıştır. Araştırmanın örneklemi 2020-2021 Eğitim Öğretim y1lında Manisa ilinde ortaokullarda öğrenim görmekte olan 273 öğrenciden oluşmaktadır. Araştırmanın örneklemi seçkisiz olmayan örnekleme yöntemlerinden olan uygun örnekleme yöntemi ile belirlenmiştir. Araştırmanın verilerinin elde edilmesinde Çocuklar İçin Öfke Ölçeği, Saldırganlık Ölçeği ve Çocuklar İçin Problem Çözme Envanteri kullanılmıştır. Verilerin analizi, t-testi, Spearman Korelasyon Analizi ve Çoklu Regresyon Analizi ile incelenmiştir. Araştırmanın bulgularına bakıldığında, kız öğrencilerin öfke düzeyleri erkek öğrencilerden daha yüksek düzeyde olduğu bulunmuştur. Erkek öğrencilerin saldırganlık düzeyleri kızlardan daha yüksektir. Öfke ile saldırganlık arasında pozitif yönlü, öfke düzeyleri ile öz denetim, kaçınma ve toplam problem çözme arasında negatif bir ilişki saptanmışır. Çalışmanın bir diğer bulgusu da öfke ve saldırganlık problem çözme becerileri tarafindan yordanmaktadır. Öğrencilerde problem çözme ile öfke ve saldırganlık ilişkisi negatif yönde anlamlı bulunmuştur.
\end{abstract} solving skills in secondary school students. Turkish Psychological Counseling and Guidance Journal, 11(63), 577-590. 


\section{INTRODUCTION}

In recent years, it has been observed that violent behavior among students in schools has become more widespread (Bacıoglu \& Özdemir, 2012). Violence in schools has the potential to negatively impact students' development. Students who are unable to establish a respectable personality may become violent in school (Akan, 2021). Students face a wide range of issues in their daily lives and in many social environments. To deal with these challenges, students must use their problem-solving skills (Ocak, Doğruel, \& Tepe, 2021). The World Health Organization defines adolescence as the first period of growth and development between childhood and adulthood (Sarldağ, 2014). Adolescence is a period of rapid maturation and development in terms of psychological, biological, social, and cognitive aspects (Steinberg, 2007). Adolescence is a risky period in which emotional intensities vary a lot (Traş and Atış, 2020). Some knowledge, skills, and experiences that should be acquired during adolescence are extremely important in the process of teenagers participating in society and assuming their place among adults (Duran \& Eldeleklioğlu, 2005). Individuals with problem-solving skills are more likely to seek out constructive solutions rather than displaying aggressive behaviors (Uzun \& Avc1, 2021).

It is important for adolescents to acquire positive problem-solving skills in terms of reducing anger and aggression behaviors (Arslan, Hamarta, Arslan, \& Sayg1n, 2010; Memnun \& Kanbur, 2020). Problem solving, according to Durmaz and Altun (2014), is "understanding what to do in the face of challenging situations where you don't know what to do." When a person faces a problem, problem solving is a process that incorporates cognitive explanations of the problem and begins to draw conclusions about the solution, leading to the person to take an action (Robertson, 2017). The content of the problemsolving process includes a number of activities. These activities are behavioral, cognitive, and emotional activities. Changing the individual's problem status and emotions is quite beneficial in solving the situation (Sophonhiranraka, et al., 2015; Loksa \& Ko, 2016). The acquisition of problem-solving skills during childhood ensures the acquisition of skills that will serve as the foundation for maturity (Uzak and Baran, 2021). A great number of studies on problem solving were found when the related literature was studied (AlMutairi, 2015; Arslan et al., 2010; Balkan \& Eliöz (2020); Deniz, Arslan and Hamarta, 2002; Mulrey, 2017; Mahulae, Sirait \& Sirait, 2017; Sumitha and Jose, 2016; Serin, 2019; Ocak, Gürbüz and Tepe, 2021; Yavuzer, Karataş, Gündoğdu, 2013; Yıldız and Ekşisu, 2011).

Adolescence is seen as a difficult period for the development of anger feelings (Reck et al., 2019). There is a link between anger and other feelings. Anger is associated with increased anxiety and concerns, as well as feelings of grief and guilt (Cassiello-Robbins \& Barlow, 2016). Anger is an emotional reaction to unfulfilled goals, unfulfilled wishes, and unfavorable outcomes. However, it is recognized as an emotion that, if not managed properly, can cause significant harm (Kunzmann \& Thomas, 2014; Shields et. al., 2016; Karataş \& Çelikkaleli, 2018). Anger can manifest itself in a variety of psychological, verbal, and actionable ways (Averill, 2012). The trivialization of personal rights, humiliation, oppression, cynical and contemptuous attitudes, and violations of recognized social norms are all reasons that can provoke anger (Moon \& Cho, 2015). Anger reactions can be perceived as dangerous, aggressive, suppressed, and threatening behaviors by people from various cultures, according to Gerhart et al., (2020). Anger and agression have an impact on the individual who is angry first, then on those around him. In this regard, anger that is not communicated in a healthy manner might be viewed as a major threat to human life (Batıün, 2004). Anger is more closely linked to feelings and behaviors. Aggression, on the other hand, refers to activities that are destructive or harmful to other people or things. 
Aggressive behaviors are frequently related to emotional anger states and intentionally cause physical harm, psychological harm, or discomfort to others (Krahé, 2013; Colasente et al., 2015, Cui, et al., 2016). Anger and aggression have negative short-and long-term outcomes, including direct fighting and violence, as well as indirect learning difficulties and social adjustment issues (Ladd et al., 2014). As a result, educators must address the anger-aggression link in order to improve children's and adolescents' behavioral functioning and well-being (Cooley et al., 2012; Malti et al., 2012; Colasente et al., 2015). Reactive aggression is more prevalent in primary schools, but intentional aggression is more prevalent in secondary schools (Uz-Baş, z, \& Topçu Kabasakal, 2012). Intentional aggression, as opposed to reactive aggression, has been related to advanced antisocial behaviors and guilt (Miller \& Lynam, 2006).

Aggression is related to a variety of major difficulties in people of all ages, according to Hicks (2018), particularly in young children, adolescents, and developing adults. School counselors providing appropriate psychological counseling services, particularly during the pre-adolescent period, will assist in the positive change and development of adolescents throughout this time (Ladd, et al.,2014; Hosseinpour et al., 2021; Serin, 2019). According to studies, students are exposed to some aggressive behaviors in the school environment. According to Uz Baş \& Kabasakal (2010), nearly 40\% of students at pre-adolescent age participated in physical violence at least once in eighth grade. It is observed that violent behavior among students in schools is becoming more and more prevalent (Bacioğlu \& Özdemir, 2012). It is important for young people to gain awareness and insight into their own lives and learn how to deal with destructive emotions in some way for their happiness in later life (Kara ve Deniz, 2021).

When looking through the related literature, it has been found that there are numerous studies on aggression and anger (Akan, 2021; Akbaş, 2021; Balc1 and Kırkıç, 2019; Colasente et al. 2015; Çavdar, 2018; Deniz et al., 2018; Fives et al., 2011; Gresham et al., 2016; Kaplan, 2007; Kılıç, 2020; Özdoğan, Haspolat, Çelik, \& Yalçın, 2021; Öztaban and Adana, 2015; Serin and Genç, 2011; Serin, 2019; Warburton, and Anderson, 2015.).

There was no study that dealt with anger, aggression, and problem-solving skills in secondary school students when the studies on anger, aggression, and problem solving were reviewed. The fact that adolescents in secondary school are undergoing rapid and unpredictable physical, psychological, and social changes poses a health risk for this group of people. In this context, it is critical to identify the health risks associated with this group's behaviors, to reveal protective measures, to take the appropriate precautions, and for all adults to have sufficient knowledge of the developmental characteristics of this period. Few research, especially in secondary school children, is known to exist on the association between anger, aggression, and problem-solving skills. The findings of this study are expected to provide vital hints to school counselors on how to reduce anger and violent behaviors in secondary school students while maintaining improvement in problem-solving skills. Reduced levels of aggression and anger, as well as individuals who can effectively cope with aggression and anger and learn positive problem-solving skills, are all thought to be important in protecting society's psychological health. The goal of this study is to discover the links between anger and aggression behaviors and problem-solving skills in secondary school students in this context. From this point of view, these variables can be considered as important clues in studies to be carried out especially to determine risk groups. In other words, if there is an inadequacy in the problem-solving skills of the individuals, problem-solving skills of adolescents can be increased by considering that this person may also have high feelings of anger and aggression. Students with high anger management skills and feelings of aggression can be reached. In the 
screening studies to be carried out, risk groups that perceive themselves as inadequate in terms of problem solving skills and have high levels of anger and impulsivity can be identified.

\section{METHOD}

\section{Research Model}

The goal of the study was to discover the connection between secondary school students' levels of anger, aggression, and problem-solving. Accordingly, the correlational survey method was used in the study. This model is a method of empirical analysis used to evaluate the interactions between more than one components, and examines the interaction between variables (Karasar, 2012).

\section{Participants}

The sample of the research consists of students studying in secondary schools in Akhisar province of Manisa city. The study included 273 students, with 146 (53\%) girls and 127 (46.5\%) boys. The convenience sampling method was used to determine the sample size in this study. In the convenience sampling method, the people who will be included in the sample are chosen by the researcher using nonrandom methods, and each person must meet the inclusion criteria.

\section{Ethical Statement}

This research was completed in line with the Helsinki Declaration. In line with this, the study was investigated and permitted by European universiyt of Lefke Scientific Research and Ethical Review Board. Additionally, data tools in the study were only distributed to volunteer participants. All participants provided informed consent. Additionally, participants were informed that they could withdraw from the study at any time during data collection.

\section{Procedure}

This research was carried out in the 2020-2021 academic year. Access to students was provided through their parents and students were provided to fill out the online questionnaire. The questionnaire form was prepared through an online questionnaire platform.

\section{Data Collection Tools}

Anger Scale for Children: It was developed by Bulut Serin and Serin (2011) to determine the anger levels of primary school 4th, 5th, 6th, 7th and 8th grade students. There are 23 items on the onedimensional scale. The scale is in the form of "I never do, I do it occasionally, and I always do" and is rated on a three-point Likert scale. In the study of Bulut Serin and Serin (2011) the Cronbach Alpha reliability coefficient of the scale was found to be 0.92 . The Cronbach Alpha reliability coefficient of the scale was determined as .91 in this study. The total score obtained from the scale indicates that the anger level is high.

Aggression Scale. It was created by Şahin (2001) to determine the level of aggression. The scale is onedimensional and has 18 items. The scale is in the form of "I never do, I do it occasionally, and I always do" and is rated on a three-point Likert scale. The Cronbach Alpha reliability coefficient of the scale was found to be .77 in a study by Şahin (2001). The Cronbach Alpha reliability coefficient of the scale was found to be .76 in this study. The scale's total score indicates that the level of aggression is high.

Problem Solving Inventory for Children. Serin, Bulut Serin, and Saygill (2010) generated it to evaluate primary school students' problem-solving abilities. There are 24 items in the inventory, with three sub- 
dimensions. "Confidence in problem-solving ability" is the first sub-dimension; "Self-control" is the second sub-dimension; and "Avoidance" is the third sub-dimension. The scale scores items in the subdimensions of self-control and avoidance in reverse order. The Cronbach alpha reliability coefficients for confidence in problem-solving skills were .85; .78 for self-control, and .66 for avoidance in Serin, Bulut Serin, and Sayg1lı's (2010) study.

\section{Data Collection and Analysis}

The Kolmogrov Smirnov test was implemented to measure the normal distribution of the scores acquired from the scales during the analysis of the research data. The t-test was used to determine whether the scores obtained by the students from the scales were differentiated according to various parameters. Spearman Correlation method was conducted to analyse the relationship between the scores obtained from the measures in the study. The students' levels of anger and aggression were examined using multiple regression analysis to predict the Children's Problem-Solving Inventory and its sub-dimensions scores. The statistical significance level of the data was accepted as $\mathrm{p}<.05$.

\section{RESULTS}

\section{Findings on the Difference between Middle School Students' Anger, Aggression and Problem-} Solving Levels by Gender

Table 1 summarizes the results of the t-test, which was used to examine if there was any gender difference in the participants' scores on the anger, aggression, and problem-solving inventory.

\begin{tabular}{|c|c|c|c|c|c|c|}
\hline Scales & Gender & $\mathrm{n}$ & Mean & Std. Dev. & t-value & p-value \\
\hline \multirow{2}{*}{ Anger } & Female & 146 & 46.821 & 9.734 & \multirow{2}{*}{2.482} & \multirow{2}{*}{$.014 *$} \\
\hline & Male & 127 & 44.015 & 8.818 & & \\
\hline \multirow{2}{*}{ Agression } & Female & 146 & 26.205 & 4.030 & \multirow{2}{*}{1.903} & \multirow{2}{*}{.058} \\
\hline & Male & 127 & 27.212 & 4.713 & & \\
\hline \multirow{2}{*}{ Problem solving Confidence } & Female & 146 & 38.890 & 5.440 & \multirow{2}{*}{.950} & \multirow{2}{*}{.343} \\
\hline & Male & 127 & 38.212 & 6.345 & & \\
\hline \multirow{2}{*}{ Problem solving Self-Control } & Female & 146 & 20.431 & 4.378 & \multirow{2}{*}{2.995} & \multirow{2}{*}{$.003 *$} \\
\hline & Male & 127 & 22.102 & 4.838 & & \\
\hline \multirow{2}{*}{ Problem solving Avoidance } & Female & 146 & 18.068 & 3.204 & \multirow{2}{*}{1.910} & \multirow{2}{*}{.051} \\
\hline & Male & 127 & 18.803 & 2.900 & & \\
\hline \multirow{2}{*}{ Total problem solving } & Female & 146 & 77.390 & 8.408 & \multirow{2}{*}{1.854} & \multirow{2}{*}{.065} \\
\hline & Male & 127 & 79.118 & 6.747 & & \\
\hline
\end{tabular}

${ }^{* \mathrm{p}<.05}$

In Table 1, a significant difference was found between the anger and problem solving self-control subdimensions according to the gender of the students $(\mathrm{t}=2.482, \mathrm{p}<.05 ; \mathrm{t}=2.995, \mathrm{p}<.05)$. It was observed that the anger levels of female students were higher than male students (mean=46.821). It was found that male students' self-control sub-dimension scores were higher than female students (mean=22.102).

Findings Regarding the Relationships between Anger, Aggression, and Problem-Solving Skills of the Participants

To see the relationship between the variables in the study and to help with interpretations and regression analysis evaluations, correlation analysis was conducted. Pearson Product-Moment Correlation was used 
to investigate the relationship between the variables of Anger, Aggression, and Problem-Solving Skills. The analysis findings are presented in Table 2.

Table 2. The Anger, Aggression and Problem-Solving Relationship of the Participants

\begin{tabular}{llllllll}
\hline Variables & & Anger & Agression & Confidence & Self-control & Avoidance & $\begin{array}{l}\text { Total problem } \\
\text { solving }\end{array}$ \\
\hline Anger & $\mathrm{r}$ & 1.000 & $.369^{* *}$ & .004 & $-.450^{* *}$ & $-.351^{* *}$ & $-.350^{* *}$ \\
& $\mathrm{p}$ & & $\mathbf{. 0 0 0}$ & .954 & $\mathbf{. 0 0 0}$ & $\mathbf{. 0 0 0}$ & $\mathbf{. 0 0 0}$ \\
Agression & $\mathrm{r}$ & 1.000 & .021 & $-.264^{* *}$ & $-.356^{* *}$ & $-.269^{* *}$ \\
& $\mathrm{p}$ & & & .725 & $\mathbf{. 0 0 0}$ & $\mathbf{. 0 0 0}$ & $\mathbf{. 0 0 0}$ \\
Confidence & $\mathrm{r}$ & $\mathrm{p}$ & & 1.000 & $-.240^{* *}$ & $.128^{*}$ & $.602^{*}$ \\
& $\mathrm{r}$ & & & $\mathbf{. 0 0 0}$ & $\mathbf{. 0 3 4}$ & $\mathbf{. 0 0 0}$ \\
Self-control & $\mathrm{r}$ & & & 1.000 & $.438^{* *}$ & $.513^{* *}$ \\
& $\mathrm{p}$ & & & & .000 & $\mathbf{. 0 0 0}$ \\
Avoidance & $\mathrm{r}$ & $\mathrm{p}$ & & & & 1.000 & $.689^{* *}$ \\
Total Problem & $\mathrm{r}$ & & & & & $\mathbf{. 0 0 0}$ \\
Solving & $\mathrm{p}$ & & & & & 1.000
\end{tabular}

In Table 2, there was a positive relationship between participants' anger and aggression $(\mathrm{r}=.369 ; \mathrm{p}<.01)$, negative relationship between problem-solving self-control $(r=-.450 ; p<.01)$, negative relationship between problem-solving avoidance sub-dimension $(\mathrm{r}=-.350 ; \mathrm{p}<.01)$, and a negative relationship between total problem solving $(r=-.351 ; \mathrm{p}<.01)$.

There was a negative correlation between aggression scores and problem-solving self-control subdimension $(\mathrm{r}=.264 ; \mathrm{p}<.01)$; a negative correlation between problem solving avoidance sub-dimension $(\mathrm{r}=-.356 ; \mathrm{p}<.01)$; and a negative correlation between total problem solving $(\mathrm{r}=-.269 ; \mathrm{p}<.01)$.

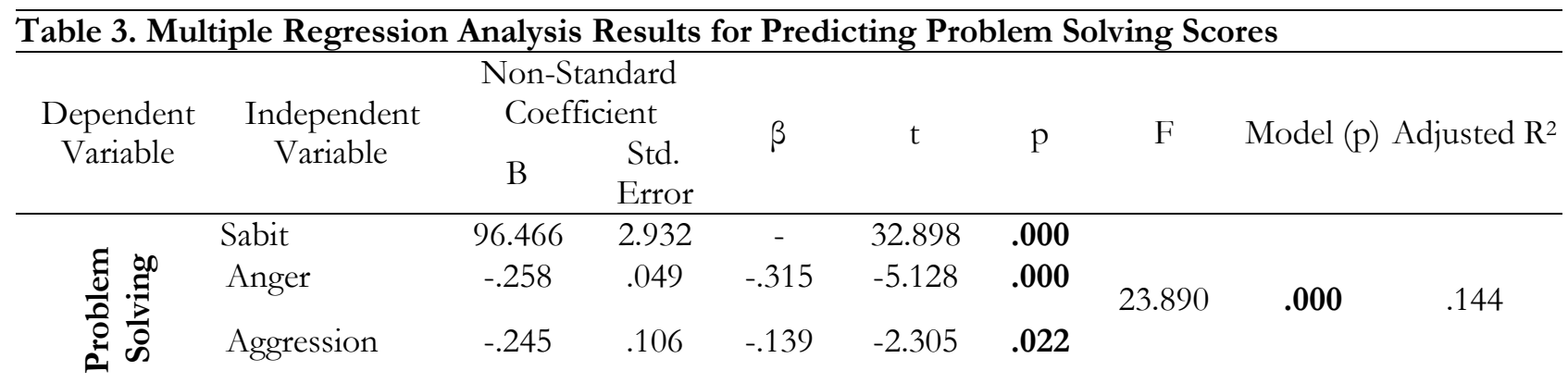

In Table 3, at the end of the multiple regression analysis of participants' Anger and Aggression scores predicting their Problem-Solving scores, the percentage of anger $(\beta=-.315, \mathrm{p}<.01$; negative $)$ and aggression $(\beta=-.139, \mathrm{p}<.01$; negative) levels were determined to have an effect at 95 confidence level $(\mathrm{R} 2=.144 \mathrm{p}<.01)$. The standardized regression coefficient $(\mathrm{B})$ revealed that the scores for "anger" and "aggression" were statistically significant $(\mathrm{R}=.404, \mathrm{R} 2=.163, \mathrm{p}<.001)$. The definement percentage of independent variables of regression analysis to the dependent variable was $14 \%$.

\section{DISCUSSION}

It was discovered that individuals' anger levels changed greatly depending on their gender. As a result, female students' anger levels were shown to be higher than male students'. According to the studies of Evren, et al., 2015); Kılıç (2020); Traş and Atış (2020), the anger level of women was found to be higher than that of men. This discovery could be due to a variety of factors. It is considered that the oppressive, 
authoritarian, and restrictive parental attitudes that are more prevalent in girls than in boys may lead to higher anger feelings in girls. Male students scored higher on aggression than female students, although the difference was not significant (Deniz, Arslan, \& Hamarta, 2002), and Serin and Mutluoğlu (2010) reached a similar conclusion in their studies. The fact that female students' aggression scores are similar to male students' aggression scores is a significant finding in terms of demonstrating that girls' aggressive behaviors in secondary school are similar to those of male students. In some studies, aggression levels of male students were found to be higher than female students (Balat \& Akman, 2006; Giles \& Heyman, 2005; Fives et al., 2011; Özdoğan, Haspolat, Çelik, \& Yalçın, 2021; Uz-Bas, Öz and Topçu Kabasakal, 2012). These studies have come up with a variety of results when it comes to these variables. When the available data on anger and aggression is analyzed by gender, adolescent problems like anger and aggression may become permanent over time, leading to bad scenarios like violent actions in the future. As a result, preventive psychological counseling services, such as anger management programs, can help students express themselves without resorting to violence throughout the secondary school period, which includes the pre-adolescent years.

In the problem-solving "self-control" dimension of the participants, there was a substantial gender difference. Accordingly, male students were found to have a higher level of self-control than female students (Serin, et al., 2012; Sumitha \& Jose, 2016). In the study conducted by Sevgi and Karakaya (2020), male and female students were found to have the same level of problem-solving skills. Adult attitudes that men should be more self-disciplined may explain this outcome. Between the total problem-solving skills of the participants and the sub-dimensions of confidence and avoidance, there was no significant gender difference. Some investigations (Deniz, Arslan, and Hamarta, 2002 Boldachev, 2014; Ocak, Gürbüz, and Tepe, 2021; Sayg1l, 2014; Şeb and Serin, 2017; Serin, 2019; Uzak and Baran, 2021) found similar results. It was found that problem solving behavior did not differ according to gender. Self-control behavior, which is one of the problem-solving skills that should be developed in all students in order to have a healthy adolescence, make healthy decisions, and fulfill their responsibilities, is an important ability that should be developed in all students.

Another finding of the study is that there is a link between students' levels of anger and aggression. As the anger level of the student increases, their aggression level also increases. Similar studies have identified a favorable association between anger and aggression in the literature. Özdoğan, et al. (2021), found a positive and high-level relationship between aggression and constant anger. Aggression and anger have a considerable association, according to Colasente et al. (2015) and Fives et al. (2011). Krahé and Krahé (2013); Gresham et al., (2016) found a positive link between anger, direct aggression, and indirect aggression in a sample of teenagers aged 12-17 years. Inadequate learning environments, safety and health concerns can lead to destructive behaviors among students and educators, increasing emotional and mental difficulties (Osai, Amponsah and Acommey-Mintah, 2021).

The participants' anger levels were found to have a negative link with their self-control, avoidance, and problem-solving abilities. Another study on problem solving skills indicate that problem solving skills training reduces anger levels and improves problem solving skills (Öztaban \& Adana, 2015).

Another finding of the study is that problem-solving skills are associated with lower levels of anger and aggression. As a result, it was discovered that positive problem-solving skills diminish anger and aggression. Uzun and Avc1 (2021) found that problem-solving skills were a negative predictor of aggressive behavior in children in their study. According to Arslan, et al., (2010), experienced problems 
in life promote aggression. When looking at studies on violence, aggression, and anger, it is found that adolescent students, in particular, are inefficient problem solvers and have difficulties controlling their anger and aggression (Faupel, Herrick, and Sharp, 2017; Tambunan, 2019; Akan, 2021). When the findings of this study on problem solving are evaluated, school psychological counselors should implement preventive programs such as problem solving and anger management, which raise awareness of reducing anger, violence, and aggressive behaviors, so that students can develop a healthy personality and character starting in secondary schools.

The link between anger, aggression, and problem-solving skills in secondary school students was examined in this study. The research study group was made up of students from secondary schools in Manisa. This condition can be viewed as a limitation in terms of the generalizability and representativeness of the study results. Because only secondary school students were included in the study, generalization of the findings is limited to this participant group. Other levels and age groups were not included. Online questionnaires were used to collect data for the study. This can also be viewed as a limitation. On the other hand, the findings of this study are expected to make original contributions to the field.

The following recommendations are given in light of the study's findings. Female students were found to have higher levels of anger than male students in the study. Aggression levels of male students and aggression levels of female students were found to be similar to each other. Another finding of the study is that problem-solving skills are associated with lower levels of anger and aggression. For students to grow up as a healthy developing generation, psychological counselors must undertake preventive, protective, and intervention programs in schools. In order to improve students' problem-solving skills and reduce their anger and aggression levels, school counselors in schools must plan and conduct individual and group guidance programs for female and male students. It is suggested that experimental research be planned to improve the problem-solving and conflict-resolution skills of students who are prone to violence and display anger and aggressive behaviors. Practitioners who are planning to conduct studies on a comparable topic may be advised to try out different models. Qualitative studies can be conducted on the development and prevention of anger and aggression. In the future researches, experimental studies can be done on large inter-regional samples and different age groups. It is recommended to carry out studies and practices on a similar subject in a way that includes students' school, friends and families. 


\section{REFERENCES}

Akan, Y. (2021). Investigation of the effect of the "violence reduction psychoeducation program" on anger, violence and aggression levels of students. International Journal of Progressive Education, 17(1), 513-533.

Akbaş, E. (2021). Çözüm odaklı yaklaşımın adölesanlarda öfke yönetimine ve şiddet davranışına etkisi [The effect of solution focused approach on anger management and violent behavior in adolescents]. Pamukkale University Institute of Health Sciences, PhD Thesis, Denizli.

AlMutairi, A. N. M. (2015). The effect of using brainstorming strategy in developing creative problem solving skills among male students in Kuwait: A field study on Saud Al-Kharji school in Kuwait City. Journal of Education and Practice, 6(3), 136-145.

Arslan, C., Hamarta, E., Arslan, E., \& Sayg1n, Y (2010). An investigation of aggression and interpersonal problem solving in adolescents. Elemantary Education Online, 9 (1), 379-388.

Averill, J. R. (2012). Anger and aggression: An essay on emotion. Springer Science \& Business Media. https://scholar.google.com/scholar.

Bacıoğlu, S. D., \& Özdemir, Y. (2012). İlköğretim öğrencilerinin saldırgan davranışları ile yaş, cinsiyet, başarı durumu ve öfke arasındaki ilişkiler [Aggressive Behaviors in Elementary Students and Their Relationship to Age, Gender, Academic Success and Anger]. Journal of Educational Sciences Research, 2(2), 169-187.

Balat, G. U., \& Akman, B. (2006). Lise Öğrencilerinin Psikolojik Durumlarının Sosyodemografik Özelliklerine Göre İncelenmesi [̇nvestigation of the psychological status of the high school students with regard to their sociodemographic characteristics]. Journal of Child and Youth Mental Health, 13(1), 3-12.

Balc1, E., \& Kırkıc, K. A. (2019). An analysis of the relationship between aggression and anger levels of the adolescents living in orphanages. International Online Journal of Educational Sciences, 11(5), 33-58.

Balkan, Ö., \& Eliöz, M. (2020). Çocuklarda motor becerilerin problem çözme yeteneği, saldırganlık ve empati davranışları üzerine etkisi [The effect of motor skills in children to the problem solving skills, aggression and empathy behaviours]. Turkish Studies-Social, 15(3), 983-993.

Batıün, A. D. (2004). İntihar ile ilişkili bazı değişkenler: Öfke/saldırganlık, dürtüsel davranışlar, problem çözme becerileri, yaşamı sürdürme nedenleri [Some variables associated with suicide: Anger/aggression, impulsive behaviors, problem-solving skills, reasons for living]. Kriz Dergisi, 12(2), 49-61.

Boldachev, A. (2014). Natural Selection or Problem Solving. Critical Re-evaluation of Karl Popper's Evolutionism. Studia Humana, 3(3), 29-42.

Bulut Serin, N., \& Genç, H. (2011). Grupla öfke denetimi eğitiminin ergenlerin öfke denetimi becerilerine etkisi [The effects of anger management education on the anger management skills of adolescents] TED-Education and Science, 36 (159), 236-254.

Cassiello-Robbins, C., \& Barlow, D. H. (2016). Anger: The unrecognized emotion in emotional disorders. Clinical Psychology: Science and Practice, 23(1), 66-85.

Colasante, T., Zuffianò, A., \& Malti, T. (2015). Do moral emotions buffer the anger-aggression link in children and adolescents? Journal of Applied Developmental Psychology, 41, 1-7.

Cooley, S., Elenbaas, L., \& Killen, M. (2012). Moral judgments and emotions: Adolescents' evaluations in intergroup social exclusion contexts. New Directions for Youth Development, 136, 41-57.

Cui, L., Colasante, T., Malti, T., Ribeaud, D., \& Eisner, M. P. (2016). Dual trajectories of reactive and proactive aggression from mid-childhood to early adolescence: Relations to sensation seeking, risk taking, and moral reasoning. Journal of abnormal child psychology, 44(4), 663-675.

Deniz, M. E., Arslan, C., \& Hamarta, E. (2002). Lise öğrencilerinin problem çözme becerilerinin çeşitli değişkenler açısından incelenmesi [Problem Solving Skills of High School Students]. Educational Management in Theory and Practice, 31(31), 374-389. 
Deniz, M. E., Kapıcıŏ̆lu, S., Yüksel, B. Ö., Özbağır, T. İ., \& Erus, S. M. (2018). Ergenlerde saldırganlık ve sosyal beceri davranışlarının yordayıcısı olarak anne baba tutumları (Parental Attitudes As a Predictor of Aggression and Social Skills Behaviors in Adolescents]. Yuldrz Institute of Social Sciences joumal 2(1), 1-11.

Durmaz, B., \& Altun, M. (2014). Ortaokul öğrencilerinin problem çözme stratejilerini kullanma düzeyleri [The Usage of the Problem Solving Strategies of the Secondary Students]. Mehmet Akif Ersoy University Faculty of Education Journal, 1(30), 73-94.

Evren, C., Bozkurt, M., Ciftci Demirci, A., Evren, B., Can, Y., \& Umut, G. (2015). Gender differences according to psychological and behavioral variables among 10th grade students in Istanbul. Anatolian Journal of Psychiatry/Anadolu Psikiyatri Dergisi, 16(2), 77-84.

Faupel, A., Herrick, E., \& Sharp, P. M. (2017). Anger management: A practical guide for teachers. Routledge.

Fives, C. J., Kong, G., Fuller, J. R., \& DiGiuseppe, R. (2011). Anger, aggression, and irrational beliefs in adolescents. Cognitive therapy and research, 35(3), 199-208.

Gerhart, J., Duberstein, P., Paull, D., O’Mahony, S., Burns, J., DeNicolo, M., \& Hoerger, M. (2020). Geopersonality of preventable death in the United States: anger-prone states and opioid deaths. American Journal of Hospice and Palliative Medicine, 37(8), 624-631.

Giles, J. W., \& Heyman, G.D. (2005). Young children's about the relationship between gender and agressive behavior. Child Development, 76(1), 107-121. 89.

Gresham, D., Melvin, G. A., \& Gullone, E. (2016). The role of anger in the relationship between internalising symptoms and aggression in adolescents. Journal of Child and Family Studies, 25(9), 2674-2682.

Hicks, S. (2018). The role of emotion regulation in the relationship between trait anger and relational aggression. (Master's Theses) A Showcase of Scholarship, Research, and Creativity at the University of Southern Mississippi.

Hosseinpour, M., Smith, J., Williams, B., Clouser, J., Anastasio, I., \& Haleem, K. (2021). Comparative Analysis of Aggressive-Driving and Distracted-Driving Crashes Involving Commercial Motor Vehicles in Kentucky. In International Conference on Transportation and Development 2021 (pp. 272-284).

Karataş, Z., \& Çelikkaleli, Ö. (2018). Beliren yetişkinlikte intihar olasıllğı: stresle başetme, öfke ve cinsiyet açısından bir inceleme[Suicide probability in emerging adulthood: an analysis in terms of coping with stress, anger and gender]. Mersin University Journal of the Faculty of Education, 14(1), 450-462.

Kaplan, A. (2007). Öfke yönetimi becerileri programmm ilkögrretim 5. sme ögrencilerinin saldrrganhle ve benlike saygısı düreylerine etkisi [The effects of anger management skills program on the levels of agression and self-esteem of primary school students in the fifth grades], (Unpublished Master Thesis). Dokuz Eylül University, İzmir.

Kara, E., \& Deniz, M. E. (2021). An examination of irrational relationship beliefs and perfectionism as the predictors of coping with romantic jealousy. Turkish International Journal of Special Education and Guidance \& Counselling (TIJSEG) ISSN: 1300-7432, 10(2), 184-196.

Kılıç, C. (2020). Saldırganlık üzerine yapılan psikolojik danışma ve rehberlik ve psikoloji doktora tezlerinin incelenmesi [A Review of Psychological Counselling and Psychology Dissertations on Aggression]. Journal of Innovative Research in Teacher Education/Ögretmen Eg̈itiminde Yenilikçi Araştrmalar Dergisi, 1(1), 01-17.

Krahé, B., \& Krahé, B. (2013). The social psychology of aggression. Psychology Press.

Kunzmann, U., ve Thomas, S. (2014). Multidirectional age differences in anger and sadness. Psychology and Aging, 29(1), 16.

Ladd, G. W., Ettekal, I., Kochenderfer- Ladd, B., Rudolph, K. D., \& Andrews, R. K. (2014). Relations among chronic peer group rejection, maladaptive behavioral dispositions, and early adolescents' peer perceptions. Child Development, 85(3), 971-988. 
Loksa, D., \& Ko, A. J. (2016). The role of self-regulation in programming problem solving process and success. In Proceedings of the 2016 ACM conference on international computing education research (pp. 83-91).

Mahulae, P. S., Sirait, M., \& Sirait, M. (2017). The effect of inquiry training learning model using PhET media and scientific attitude on students' science process skills. IOSR Journal of Research \& Method in Education, 7(5), 24 29.

Malti, T., Eisenberg, N., Kim, H., \& Buchmann, M. (2013). Developmental trajectories of sympathy, moral emotion attributions, and moral reasoning: The role of parental support. Social Development, 22(4). 773-793.

Moon, S. H., \& Cho, H. H. (2015). Anger, anger expression types, problem behaviors, and suicide probability in adolescent women using cluster analysis. Korean Journal of Women Health Nursing, 21(2), 128-138.

Mulrey, B. C. (2017). Increasing social problem-solving skills in early childhood (Doctoral dissertation, New England College).

Memnun, D. S., \& Kanbur, N. İ. (2020). Üçüncü sınıf öğrencilerinin okuma becerilerine göre problem çözme başarıları ve çözüm sürecinde karşılaştıkları güçlükler. OPUS Uluslararası Toplum Araştırmaları Dergisi, 15(22), 927-965.

Miller, J. D., \& Lynam, D. R. (2006). Reactive and proactive aggression: Similarities and differences. Personality and Individual Differences, 41, 1469-1480. https://doi.org/10.1016/i.paid.2006.06.004

Nihan, U., \& Baran, G. (2021). Ergenlerde iletişim becerileri ve problem çözme becerilerinin incelenmesi [the problem-solving achievements and the difficulties in solving process of third grade students according to reading skills]. IBAD Journal of Social Sciences, (11), 315-342.

Ocak, G., Doğruel, A. B., \& Tepe, M. E. (2021). An analysis of the relationship between problem solving skills and scientific attitudes of secondary school students. International Journal of Contemporary Educational Research, 8(1), 72-83. DOI: https://doi.org/10.33200/ijcer.780710

Osai, J. A., Amponsah, K. D., Ampadu, E., \& Commey-Mintah, P. (2021). Teachers'experiences with overcrowded classrooms in a basic school in Ghana. International Online Journal of Primary Education (IOJPE), 10(1), 73-88.

Özdoğan, A. Ç., Haspolat, N. K., Çelik, O., \& Yalçın, R. Ü. (2021). Ergenlerde Reaktif-Proaktif Saldırganlık ve Bilişsel Esneklik: Öfkenin Arac1 Rolü [Reactive-Proactive Aggression and Cognitive Flexibility in Adolescents: The Mediating Role of Anger]. Anadolu Journal of Educational Sciences International, 11(2), 826851.

Öztaban, Ş., \& Adana, F. (2015). Lise öğrencisi erkek ergenlerde problem çözme eğitiminin; problem çözme becerisi, kişilerarası ilişki tarzı ve öfke kontrolü üzerine etkisi [The effect on their problem solving skills, interpersonal style and anger control of problem-solving training in male adolescents who are high school students]. Hemșirelikte Arastrma Gelistirme Dergisi, 17(1), 21-36.

Reck, K. L., Tiret, H., Meuser, C., Perry, G., \& Quintino-Aranda, V. (2019). RELAX Alternatives to Anger: Examining the Experiences of Latino Adults in an Anger Management Program. Journal of Human Sciences and Extension, 7(3), 206-230.

Robertson, S. I. (2017). Problem Solving Perspectives from Cognition and Neuroscience. New York: Routledge.

Sarıdağ, B. (2014). Doğu Anadolu bölgesinde yaşayan adölesan ve yetişkinlerin beslenme alışkanlıkları ile yeme tutum ve davranışlarının belirlenmesi [An investigation of dietary habits, eating attitudes and behaviours in adolescents and adults from Eastern Anatolia region in Turkey]. (Master's Theses) Başkent Üniversitesi, Sağllk Bilimleri Enstitüsü, Ankara.

Serin, N. B., Pehlivan, A., Serin, O., Şahin, S., \& Saygili, G. (2012). Relationship between intelligence areas and interpersonal problem solving skills according to multiple intelligences theory. International Online Journal of Primary Education (IOJPE), 1(2), 16-24 
Serin, O., Serin, N. B., \& Sayg1l, G. (2010). İlköğretim düzeyindeki çocuklar için problem çözme envanteri'nin (ÇPÇE) geliştirilmesi [Developing Problem Solving Inventory for Children at the Level of Primary Education (PSIC)]. Elementary Education Online, 9(2), 46-458. http://ilkogretim-online.org.tr/

Serin, N. B. (2019). The impact of anger management training on anger, aggression and problem-solving skills of primary school students. International Online Journal of Education and Teaching, 6(3), 525-543.

Sevgi, S., \& Karakaya, M. (2020). Investigation of Metacognition Awareness Levels and Problem Solving Skills of Middle School Students. International Online Journal of Primary Education (IOJPE), 9(2), 260-270.

Shields, G. S., Moons, W. G., Tewell, C. A., \& Yonelinas, A. P. (2016). The effect of negative affect on cognition: Anxiety, not anger, impairs executive function. Emotion, 16(6), 792.

Simamora, R. E., Sidabutar, D. R., \& Surya, E. (2017). Improving learning activity and students' problem solving skill through problem based learning (PBL) in junior high school. International Journal of Sciences: Basic and Applied Research (IJSBAR), 33(2), 321-331.

Sophonhiranraka, S., Suwannatthachoteb, P., \& Ngudgratokec, S. (2015). Factors affecting creative problem solving in the blended learning environment: A review of the literature. Procedia-Social and Behavioral Sciences, 174(1982), 2130-2136.

Steinberg, L. (2007). Risk taking in adolescence: New perspectives from brain and behavioral science. Current Directions in Psychological Science, 16(2), 55-59.

Sullivan, T. N., Garthe, R. C., Goncy, E. A., Carlson, M. M., \& Behrhorst, K. L. (2017). Longitudinal relations between beliefs supporting aggression, anger regulation, and dating aggression among early adolescents. Journal of Youth And Adolescence, 46(5), 982-994.

Sumitha, S., \& Jose, R. (2016). Requisite for Honing the Problem Solving Skill of Early Adolescents in the Digital Era. Journal on Educational Psychology, 10(1), 36-43.

Şahin, H. (2004). Saldırganlık ölçeği geçerlik güvenirlik çalışması [Aggression scale validity and reliability study]. Süleyman Demirel University Journal of Burdur Faculty of Education, 5, 180-190.

Şeb, G., \& Serin, N.B. (2017). KKTC'de satranç eğitimi alan ve almayan ilkokul ve ortaokul öğrencilerinin problem çözme becerilerine yönelik alg1ları [Perceptions of trnc primary and secondary school students receiving chess training towards problem solving skills]. International Journal of New Trends in Arts, Sports \& Science Education, 6(3), 58-67.

Tambunan, H. (2019). The Effectiveness of the Problem Solving Strategy and the Scientific Approach to Students' Mathematical Capabilities in High Order Thinking Skills. International Electronic Journal of Mathematics Education, 14(2), 293-302.

Traş, Z., \& Atiş, Y. (2020). Investigation of the relationship between trait anger and anger expression and submissive behaviors in adolescents. Advances in Education Sciences, 2(2), 154-165.

Uzak, N., \& Baran, G. (2021). Ergenlerde iletişim becerileri ve problem çözme becerilerinin incelenmesi [Investigation of adolescent communication skills and problem solving skills]. IBAD Journal of Social Sciences, (11), 315-342.

Uz-Baş, A., Öz, S., \& Topçu Kabasakal, Z. (2012). İlköğretim ve ortaöğretim okullarında reaktif ve proaktif saldırganlık: Okul psikolojik danışmanlarının görüş ve yaklaşımları [Reactive and Proactive Aggression in Elementary and High Schools: School Counselors' Views and Approaches]. Journal of Mehmet Akif Ersoy University Faculty of Education, 23, 354-370.

Uzun, M., \& Avc1, R. (2021). Investigation of the relationships between perceived marital conflict, parents' irrational beliefs, anxiety and children's automatic thoughts, problem solving skills, and children's anxiety and aggression. Education and Science. Early Release 1-22. 
Warburton, W. A., \& Anderson, C. A. (2015). Social psychology of aggression. International Encyclopedia of The Social \& Behavioral Sciences, 1, 373-380.

Yavuzer, Y., Karataş, Z., \& Gündoğdu, R. (2013). Ergenlerin çatışma çözme davranışlarının incelenmesi: Nicel ve nitel bir çalışma [An investigation ofconflict resolution behaviours: a quantitative and qualitative study]. Journal of Hacettepe University Faculty of Education, 28(28-1), 428-440. 


\section{About Authors}

Bilge Fidan received her bachelor's degree in North Cyprus at European University of Lefke, Guidance and Psychological Counselling Department. She completed her master's degrees in Guidance and Psychological Counselling Department. She is working as a school counselor in Turkey (Ministry of National Education, Akhisar Eksen Okulları, school psychologist, Akhisar, Manisa, Turkey).

Nerguz Bulut Serin works as a Professor at the European University of Lefke, Faculty of Education, Department of Educational Sciences, Department of Counselling and Psychology. Dr. Serin, together with graduate and doctoral students, has worked on cognitive behavioural therapy, depression, anxiety, anger management, stress management, problem solving abilities, social acceptance, cyberbullying, attachment styles in children, social gender roles, social media and internet addiction at national and international level. She has many published articles and notifications.

\section{Author Contributions}

This study was conducted by all the authors working together and cooperatively. All of the authors substantially contributed to this work in each step of the study.

\section{Conflict of Interest}

It has been reported by the authors that there is no conflict of interest.

\section{Funding}

No funding support was received.

\section{Note}

This study was produced from the first author's Master dissertation, which was supervised by the second author.

\section{Ethical Statement}

This research was completed in line with the Helsinki Declaration. In line with this, the study was investigated and permitted by European universiyt of Lefke Scientific Research and Ethical Review Board. Additionally, data tools in the study were only distributed to volunteer participants. All participants provided informed consent. Additionally, participants were informed that they could withdraw from the study at any time during data collection.

Ethics Committee Name: European University of Lefke, University Ethics Committee (ÜEK) Approval Date: 24/09/2021.

Approval Document Number: ÜEK/65/01/09/2122/04 